www.volsu.ru

DOI: https://doi.org/10.15688/nsr.jvolsu.2019.1.4

UDC 632.4.01/08:632.931.4

LBC 44.9

\title{
DUTCH ELM DISEASE: TOPICAL PROTECTIVE MEASURES IN PLANTINGS OF THE LOWER VOLGA REGION
}

\author{
Elena A. Kryukova \\ Federal Scientific Centre of Agroecology, Complex Melioration and Protective Afforestation \\ of the Russian Academy of Sciences, Volgograd, Russian Federation \\ Tatyana V. Kuznetsova \\ Federal Scientific Centre of Agroecology, Complex Melioration and Protective Afforestation \\ of the Russian Academy of Sciences, Volgograd, Russian Federation

\section{Svetlana V. Kolmukidi} \\ Federal Scientific Centre of Agroecology, Complex Melioration and Protective Afforestation \\ of the Russian Academy of Sciences, Volgograd, Russian Federation; \\ Volgograd State University, Volgograd, Russian Federation
}

\begin{abstract}
The article presents the results of studies of a malicious disease of the elm, which causes vascular pathology - tracheomycosis, called the Dutch elm disease. Observations, collection and analysis of material infected with diseases were performed in plantations of the Volgograd region. Laboratory and field experiments were carried out according to appropriate generally accepted methods. We have developed principles and methods for the evaluation and selection of resistant to vascular mycoses of the elm, which have been reduced to the selection in plantations of healthy trees resistant to vascular mycoses; employment in studies of the species of elm, but mainly Ulmus pumila L. of the local population, as the most sustainable; employment of the inoculation method in assessing resistance to a highly aggressive pathogen strain; studying the mechanisms of resistance on biochemical grounds; vegetative propagation (root cuttings) for subsequent testing on the stability of selected forms; the selection and study of the stability of seed progeny of selected clones. Testing fungicides against causative agents of vascular mycoses was carried out as a prophylactic measure - disinfection of saw cuts after felling recovery. Highly effective were the systemic drugs Benomil and Strobi, penetrating into the depth of the wood and exhibiting protective functions. Bishal forms an oily film on the surface of the cuts, performing mechanical and preventive protection. On the trees, the cuts of which were treated with the Fitosporin$M$ biological preparation, there was also no spread of pathogenic infection. The effectiveness of the preparations was verified by laboratory sowing of samples taken from the treated cut on agar nutrient media. The highest efficacy of systemic drugs was in the range of $95.0-99.2 \%$. As a result of many years of research (over 30 years), continuing to the present, according to the evaluation and selection of varying degrees of resistance of elm species, forms, hybrids and clones, highly resistant Ulmus pumila (typical) and its forms have been identified. They multiplied vegetatively and seed, then passed the test for resistance to the pathogen and are recommended For production purposes. According to the results of the audit, urban forestry techniques are effectively implemented in the urban ecosystem.

Key words: plant resistance, susceptibility, infection, heterogeneity, forms, clones, deep healing pruning, therapeutic and preventive measures.
\end{abstract}


УДК 632.4.01/08:632.931.4

ББК 44.9

\title{
ГОЛЛАНДСКАЯ БОЛЕЗНЬ ИЛЬМОВЫХ: \\ АКТУАЛЬНЫЕ ЗАЩИТНЫЕ МЕРОПРИЯТИЯ \\ В НАСАЖДЕНИЯХ НИЖНЕГО ПОВОЛЖЬЯ
}

\author{
Елена Андреевна Крюкова \\ Федеральный научный центр агроэкологии, комплексных мелиораций и защитного лесоразведения \\ Российской академии наук, г. Волгоград, Российская Федерация \\ Татьяна Владимировна Кузнецова \\ Федеральный научный центр агроэкологии, комплексных мелиораций и защитного лесоразведения \\ Российской академии наук, г. Волгоград, Российская Федерация

\section{Светлана Валерьевна Колмукиди} \\ Федеральный научный центр агроэкологии, комплексных мелиораций и защитного лесоразведения \\ Российской академии наук, г. Волгоград, Российская Федерация; \\ Волгоградский государственный университет, г. Волгоград, Российская Федерация
}

Аннотация. Представлены проблемы, вызываемые вредоносными заболеваниями ильмовых сосудистой патологией. Показаны результаты многолетних исследований (более 30 лет) по оценке и отбору различной степени устойчивости видов, форм, гибридов и клонов ильмовых. Выявлены высокоустойчивый вяз приземистый (типичный) и его формы. Размноженные вегетативным и семенным путем, они прошли проверку на устойчивость и рекомендуются для производственных целей. В урбоэкосистемы по результатам проверки эффективно внедряются лесохозяйственные приемы.

Ключевые слова: устойчивость растений, восприимчивость, инфицирование, гетерогенность, формы, клоны, глубокая оздоравливающая обрезка, лечебно-профилактические мероприятия.

Введение. Для специфических острозасушливых лесорастительных условий региона Нижнего Поволжья в степном защитном лесоразведении особую значимость приобретают насаждения ильмовых [6; 12]. Также значительное применение они находят и в урбоэкосистемах: озеленение парков, скверов, улиц [4; 8-10]. Этот род представлен здесь вязом обыкновенным, гладким (Ulmus laevis Pall.), вязом приземистым (мелколистный, перистоветвистый, или ильмовник) - Ulmus pumila L . и берестом (вяз граболистный, полевой, листоватый) - Ulmus caprinifolia Rupp. ex. Suckow. (U. campestris). Вязы обыкновенный и листоватый встречаются преимущественно в естественных лесах, а вяз приземистый только в искусственных насаждениях и используется в качестве главной породы почвозащитного и полезащитного лесоразведения. Он был завезен из Средней Азии, и с использованием его для введения в защитные лесные полосы и стал называться вязом мелко- листным. Однако некоторые систематики этот вяз считают идентичным $U$. pumila вязу приземистому [2], который в естественных условиях распространен на Дальнем Востоке и Восточной Сибири, а в искусственных - в лесоразведении юго-востока России.

В озеленении и защитном лесоразведении Нижнего Поволжья растения вяза приземистого отличаются гетерогенностью [7], полиморфизмом ряда признаков [17], по результатам обработки наших гербарных материалов систематиком ильмовых И.А. Грудзинской (институт Ботаники им. Комарова) [2] выявлено, что насаждения чаще представлены спонтанными гибридами между $U$. pumila и U. campestris. Формовое разнообразие и гибридные «берестообразные» формы отмечают сотрудники Джаныбекского стационара Института лесоведения Н.Г. Сенкевич и Г.В. Линдеман [13], проводившие исследования в защитных лесных насаждениях; Е.А. Крюкова, Г.В. Федунова в 
Нижнем Поволжье [6], в экосистемах Волгограда Т.В. Кузнецова [8]. Там, где берест отсутствует - Алматинская и Целиноградской (ныне Акмолинская) области - гибридные формы не отмечены [13].

Объект исследования. Для большинства ильмовых характерна восприимчивость к чрезвычайно вредоносной голландской болезни или трахеомикозу (графиозу). Это заболевание, вызываемое грибом (Ophiostoma ulmi) syn. Ceratocystis ulmi (Buisman) C. Moreau), за последние полвека получило широкое распространение в нашей стране и за рубежом.

Цель исследований - изучение возбудителей графиоза вязовых рода Ophiostoma, исследование их биоэкологии и агрессивности, проведение селекционной оценки на видовую устойчивость возбудителям той географической зоны, для которой отбирается данный вид растения.

Материалы и методы. Материалом исследования явились вяз гладкий (U. laevis Pall.), берест (U. caprinifolia Rupp. ex. Suckow. $=U$. campestris $)$ и вяз приземистый (U. pumila L.). Наблюдения, сбор и анализ материала, инфицированного болезнями выполнялись в насаждениях Волгоградской обл. Лабораторные и полевые эксперименты проводились по соответствующим общепринятым методикам Крюковой Е.А. [6], Кузьмичева Е.П. [9], Мощеникова Н.Б. и Е. В. Вязникова [11] и др.

Результаты и их обсуждение. По данным Комитета природных ресурсов, лесного хозяйства и экологии Волгоградской области, площади, занимаемые ильмовыми, резко сократились, в том числе сильной поражаемости их голландской болезнью [6]. Вяз обыкновенный и вяз листоватый (берест) почти полностью выпали из всякого рода насаждений и для искусственных посадок в нашей зоне не рекомендуются. Наиболее распространенным видом для искусственных насаждений остается вяз приземистый и его гибриды.

Из литературных данных $[12 ; 13]$ известно, что этот вид обладал естественным специфическим активным иммунитетом к голландской болезни и его разведение широко рекомендовалось. При перекрестном опылении совместно растущих видов ильмовых возникают гетерогенные популяции, где наряду с типичным вязом приземистым встречаются и гибридные формы, у которых сильнее проявляется признак восприимчивости к голландской болезни. Распространение болезни связывается также с наличием ильмовых заболонников, являющихся ее переносчиками.

В ряде литературных источников [3; 4; $10 ; 14 ; 15 ; 18]$ достаточно изучены экологические и биологические особенности голландской болезни, пути распространения ее, переносчики [23; 24; 25], культурально-морфологические особенности возбудителя голландской болезни [19], оценка на устойчивость и др. Однако все эти данные относятся к иным почвенно-географическим и климатическим регионам России. Для условий засушливой зоны юго-востока все эти вопросы оставались неутонченными и требовали теоретических и практических исследований. Исходя из этого, мы посчитали необходимым остановиться лишь на отдельных вопросах.

В результате проведенных многолетних исследований (с 70 гг. XX в. и до наших дней) нами при изучении культурально-морфологических свойств возбудителя болезни на видах ильмовых идентифицирован высокоагрессивный штамм $\left(B_{1}\right)$ с вяза $U$. pumila, характеризующийся массовым высоковирулентным спороношением Graphium (коремии), которые малочисленны или отсутствуют в других штаммах. Идентификация этого агрессивного штамма была подтверждена английским фитопатологом C.M. Brasier [14; 15], который неоднократно посещал Всероссийский научно-исследовательский агролесомелиоративный институт (ВНИАЛМИ), он изучал голландскую болезнь в мировом масштабе. C.M. Brasier в 1991 г. этот агрессивный штамм представил, как новый вид Ophiostoma novoulmi Brasier $[14 ; 16]$. В дальнейшем этот штамм нами использовался во всех опытных работах (искусственные инокуляции, оценка на устойчивость форм вяза, опыты с переносчиками и др.). Такой подход позволил определить зональные штаммы возбудителя, изучить их биоэкологию и агрессивность, провести селекционную оценку на видовую устойчивость к штамму возбудителя той географической зоны, для которой отбирается данный вид [5].

Ценные качества вяза с одной стороны и отсутствие эффективных мер борьбы с его 
болезнью с другой, заострило внимание исследователей на поиск устойчивых форм. Опытные работы в этом направлении проводятся в Голландии, Германии, Италии и других странах.

В нашей стране работы по оценке и отбору устойчивых к голландской болезни азиатских ильмовых были в Среднеазиатском научно-исследовательском институте лесного хозяйства Г.П. Озолиным. В результате этой работы были отобраны устойчивые клоны вяза среди азиатских видов [12].

В дальнейшем работа по изучению голландской болезни и селекции на устойчивость к ней местных видов проводилась во ВНИАЛМИ, под руководством член-корр. ВАСХНИЛ, доктора биологических наук, профессора Г.П. Озолина.

В результате изучения проблемы и проработки теоретических положений, нами были сформированы принципы и методы оценки и отбора устойчивых к трахеомикозам древесных видов, в частности ильмовых, которые свелись к следующему:

- отбор в насаждениях устойчивых к сосудистым микозам здоровых деревьев;

- использование в исследованиях видов ильмовых, но, главным образом, вяза приземистого из местной популяции, как наиболее устойчивого;

- использование метода инокуляции при оценке на устойчивость к высокоагрессивному штамму возбудителя;

- изучение механизмов устойчивости по биохимическим признакам;

- вегетативное размножение (корневыми черенками) для последующей проверки на устойчивость отобранных форм;

- отбор и изучение устойчивости семенного потомства отобранных клонов.

В основу изучения устойчивости к голландской болезни нами были положены следующие методы и приемы: искусственное заражение растений методом инокуляции высокоагрессивным штаммом; классификация испытываемых растений по степени устойчивости к трахеомикозу; размножение и отбор устойчивых растений вегетативным и семенным путем; проверка на устойчивость вегетативного и семенного потомства.

По мнению Д.Д. Вердеревского, проводить искусственное заражение необходимо агрессивной расой патогена, которая естественно возникла в природе и получила широкое распространение [1]. Нами для опытных работ по оценке устойчивости вяза из четыpeх местных штаммов был взят выделенный нами высокоагрессивный штамм $B_{1}$, изолированный из и вяза приземистого. Для выявления иммунности растения [6] необходимы индивидуальная оценка каждого из них отдельно, выбраковка неустойчивых и многократный отбор растений, высокоустойчивых к болезни. Проверку устойчивости мы проводили в течение нескольких лет, зараженные экземпляры были уничтожены, а выжившие заражали в последующие годы повторно. Устойчивыми оценивались лишь те клоны, которые после многолетних искусственных заражений оставались полностью невосприимчивыми к голландской болезни, вплоть до начала плодоношения. При изучении устойчивости различных видов вяза к болезни оценку проводили не только по видам и формам, но и по их эколого-географическому происхождению (Узбекистан, Украина, Хабаровск, Ростов и др.).

В настоящее время практически все азиатские, американские и европейские виды и разновидности ильмовых поражаются голландской болезнью в той или иной степени (см. табл. 1).

Голландский ученый Х.М. Хейбрук [20] считает, что в будущем сохранность ильмовых в Европе зависит от селекции вяза на устойчивость к графиозу. Изучение этой устойчивости, проводимые фитопатологами разных стран, свидетельствуют об относительной устойчивости вяза приземистого к голландской болезни. Некоторые авторы относят его к иммунным видам, другие - к устойчивым [21; 22]. Это свидетельствует о том, что один и тот же вид, но в разных эколого-географических условиях может иметь различную степень устойчивости к голландской болезни, что подтверждено нашими исследованиями - более устойчив среднеазиатский и дальневосточный экотипы.

Для засушливой зоны юго-востока европейской части страны работ по устойчивости местных видов ильмовых к графиозу не было. В связи с этим была поставлена цель выявить степень поражаемости видов, форм, клонов ильмовых в засушливых лесораститель- 
ных условиях и выявить степень устойчивости к возбудителю болезни, выделенному местному штамму, размножение и их внедрение в регион.

При оценке основных видов ильмовых на устойчивость к голландской болезни в засушливых условиях юго-востока России методом искусственной инокуляции штаммом $B_{1}$ на саженцах 2-3 летнего возраста были получены следующие результаты:

- вязы обыкновенный, пробковый, шершавый и берест заражались полностью (до $100 \%$ преимущественно в острой форме и в течение одного-двух лет усыхали;
- вяз приземистый и его формы (гибриды) хотя и заражались графиозом, но в различной степени, с проявлением устойчивости;

- были выявлены полностью устойчивые клоны вяза приземистого (типичного), эти клоны использованы нами для размножения их вегетативным путем (корневыми черенками) с целью создания первого маточника (1 га) устойчивого к голландской болезни;

- из семян устойчивого вяза заложен маточно-коллекционный участок (3 га),

- проверка вегетативного потомства показала 100 \% устойчивость к трахеомикозу, семенного - также высокую до 96 \%.

Таблиияа 1

\section{Устойчивость различных видов вяза к голландской болезни}

\begin{tabular}{|c|c|}
\hline $\begin{array}{c}\text { Степень } \\
\text { устойчивости }\end{array}$ & Вид вяза \\
\hline \multirow[t]{15}{*}{$\begin{array}{l}\text { Высоко } \\
\text { Восприимчивы }\end{array}$} & $\begin{array}{c}\text { Европейские виды } \\
\text { В. листоватый, берест U. foliacia Gilib. (U. carpinifolia Rupp. ex Suchow) }\end{array}$ \\
\hline & В. шершавый, горный ильм U. scabra Mill. \\
\hline & В. обыкновенный U. laevis Pall. \\
\hline & В. голландский U. hollandica Mill. \\
\hline & B. меньший U. minor Mill. \\
\hline & В. высокий U. procera Solisb. \\
\hline & В. крылатый U. Alata Michx. \\
\hline & В. пробковый U. suberosa Moench. \\
\hline & Гибрид берест х вяз приземистый (U. carpinifolia Rupp. ex G. Suchow × U. pumila L.) \\
\hline & Американские виды \\
\hline & B. американский U. americana $\mathrm{L}$. \\
\hline & В. плакучий U pendula Nutt. \\
\hline & В. кистевидный U. rasemosa Thomas. \\
\hline & В. поздний U. serotina Sorgent. \\
\hline & В. лисий, рыжий U. fulva Michx. \\
\hline \multirow[t]{8}{*}{ Восприимчив ы } & Азиатские виды \\
\hline & B. Бергмана U. Bergamaniana Schneider \\
\hline & В. Андросова U. Androssowi $i$ Litw. \\
\hline & В. густой $U$. densa Litw. \\
\hline & В. эллиптический U. elliptica C. Koch. \\
\hline & В. японский U. japonicaSarg. \\
\hline & В. лопастной U. laciniataMayr. \\
\hline & В. туркестанский U. turcestanica Regel. \\
\hline \multirow{4}{*}{$\begin{array}{l}\text { Восприимчивы } \\
\text { в слабой степени }\end{array}$} & Гибрид вяз приземистый х берест (U. pumila L. × U. carpinifolia Rupp. ex G. Suchow) \\
\hline & В. крупноплодный U. macrocarpa Hancc. \\
\hline & В. ВильсонаU. wilsoniana Schneider. \\
\hline & B. среднийU. propinqua Koidz. \\
\hline \multirow[t]{5}{*}{ Устойчивы } & B. никкийский U. nikkoensis Rut. \\
\hline & В. мелколистный, китайский U. parvifolia Jaeq. \\
\hline & B. ширазский U. sieboldiif. shirasawana (Daveau) Nakai \\
\hline & В. ЗибольдаU. Siebaldi Davean. \\
\hline & В. кожистыйU. coriana Nokai. \\
\hline \multirow[t]{3}{*}{ Высокоустойчивы } & B. приземистый типичный U. pumila L. \\
\hline & В. приземистый, ф. перисто-ветвистая U. pinnato-ramosa Dieck. \\
\hline & B. приземистый ф. жестколистная U. pumila L. \\
\hline
\end{tabular}

Примечание. Составлено по: [3; 7; 12]. 
Таким образом, окончательная проверка в результате многолетнего (более 30 лет) труда подтвердила невосприимчивость отобранных клонов к болезни, их способность давать устойчивое потомство, которые вступило в плодоношение для заготовки семян устойчивого вяза с целью внедрения его в защитное лесоразведение и озеленение в засушливых условиях Нижнего Поволжья (Волгоградская область, Калмыкия и др.)

Защита древесных пород от вредоносной сосудистой патологии - голландской болезни ильмовых путем селекционной оценки, отбора устойчивых форм, размножения и внедрения является многолетним, трудоемким, требующим специфических навыков и знаний, но признан более надежным, долговременным способом, что подтверждено рядом исследователей и результатами наших работ.

В урбанизированных экосистемах, в городском озеленении с элементами современной урбанистики актуальным является декоративность и фитосанитарное состояние ильмовых. В озеленении Волгограда и области доминирующей являются ильмовые породы, которые подвержены комплексу инфекционных заболеваний различной этиологии, в связи с этим проведение исследований по омоложению, оздоровлению, улучшению фитосанитарного состояния для повышения декоративности и жизнеспособности ильмовых насаждений весьма актуальны.

Как показали наши исследования, глубокая омолаживающая обрезка деревьев, широко применяемая в городских посадках, является одновременно и оздоравливающей, так как удаляются концевые развилки веток, являющиеся местом дополнительного питания жуков-заболонников, которые переносят споры гриба-возбудителя графиоза, удаляются ветви с очагами некрозов. В результате обрезки такого типа патоген не успевает распространиться глубже и способствовать развитию инфекционного процесса.

Распространение внутреннего поражения древесины вяза голландской болезнью диагностируется по степени усыхания кроны больного дерева - до одной трети кроны (верхушечное). Выявленная зависимость обосновывает проведение оздоровительных (санитарных) рубок - до проникновения возбудителя в при- корневую и корневую систему дерева и возобновление при этом здоровой поросли. Фигурная стрижка и формовочно-декоративная обрезка являются неотъемлемой частью лесохозяйственных мероприятий. Этими мероприятиями достигается высокий декоративно-эстетический и омолаживающий эффект насаждений, так как они являются дополнительными к «глубокой» омолаживающей обрезке.

В ходе исследований нами была разработана новая технология, включающая лечебно-профилактические мероприятия - дезинфекция спилов антисептиками с последующим закрашиванием [8]. Испытание фунгицидов против возбудителей сосудистых микозов осуществляли как профилактическое мероприятие - дезинфекция спилов после рубок оздоровления (см. табл. 2).

Против патогена, вызывающего трахеомикоз испытывали Строби, Беномил, Бишаль, Абига-ПИК, Фитоспорин-М. Из них высокоэффективными оказались системные препараты Беномил и Строби. Они проникают в глубину древесины и проявляют защитные функции. Бишаль образует маслянистую пленку на поверхности спилов, выполняя механическую и профилактическую защиту. На деревьях, спилы которых были обработаны биопрепаратом Фитоспорин-М, также не было распространения фитопатогенной инфекции. Эффективность препаратов проверялась путем лабораторного посева образцов взятых с обработанных спилов на агаризованных питательных средах. Наивысшая эффективность от системных препаратов составила в пределах 95,0-99,2\%.

Заключение. Итак, вяз - уникальная лесообразующая порода для сухостепного засушливого Поволжского региона, отличающаяся засухо-солеустойчивостью, адаптированностью к специфическим климатическим условиям. Вместе с тем вяз подвержен коварной, вредоносной сосудистой патологии голландской болезни, получившей мировое признание в поражении сем. Ulmaceae. Защита от болезней затруднена и многогранна. Во всем мире радикален путь отбора устойчивых иммунных видов и форм, для конкретных эколого-географических условий.

Наша многолетняя работа проведена для засушливого региона юго-востока Европейской части РФ, где доминирующим является 
морфобиологическое разнообразие ильмовых, отличающихся гетерогенностью и различной патологической устойчивостью. Выявлены, отобраны и размножены: устойчивый вяз приземистый (типичный) и его формы к местным условиям и штаммы возбудителя. В урбоэкосистемах, городском озеленении приемлемы и эффективны «глубокая» омолаживающая и оздоравливающая обрезки в сочетании с лечебно-профилактическими мероприятиями.

Комплекс проводимых нами исследований и внедрение их в производственных целях, это путь, способствующий эффективному оздоровлению вяза о голландской болезни, декоративности и жизнестойкости, в современных экологических условиях с меняющимся климатом.

\section{СПИСОК ЛИТЕРАТУРЫ}

1. Вердеревский, Д. Д. Иммунитет растений к паразитарным болезням / Д. Д. Вердеревский. - М. : Сельхозгиз, 1959. - 372 с.
2. Грудзинская, И. А. Заметка об Ulmus pumila L. / И. А. Грудзинская // Материал гербария Ботанического ин-та АН СССР. - Т. 21. - 1961. - 30 с.

3. Дудина, В. С. Голландская болезнь ильмовых пород: монография / В.С. Дудина. - М. : Сельхозгиз, 1938. $-46 \mathrm{c}$.

4. Калько, Г. В. Голландская болезнь вязов в Санкт-Петербурге / Г. В. Калько // Микология и фитопатология. - 2008. - Т. 42, № 6. - С. 564-572.

5. Крюкова, Е. А. Сосудистые патологии - угроза вязу в лесоразведении Поволжья / Е. А. Крюкова, С. В. Колмукиди, Т. В. Кузнецова // Вестник Российской академии сельскохозяйственных наук. 2013. - № 1. - С. 52-54.

6. Крюкова, Е. А. Сосудистые патологии в степном лесоразведении / Е. А. Крюкова, С. В. Колмукиди, И. В. Скуратов. - Волгоград : ВНИАЛМИ, 2016. $-134 \mathrm{c}$.

7. Крюкова, Е. А. Гетерогенность ильмовых и степень патологической поражаемости в лесонасаждениях Нижнего Поволжья / Е. А. Крюкова, Т. В. Кузнецова // Экология и мелиорация агроладшафтов : материалы Междунар. научно-практич. конф. молодых ученых. - Волгоград : ВНИАЛМИ, 2017.- C. 123-127.

Таблиц̧а 2

Омолаживающая обрезка в сочетании с технологией антисептирования (Кировский и Ворошиловский р-ны г. Волгограда)

\begin{tabular}{|c|c|c|c|c|c|}
\hline \multicolumn{2}{|c|}{$\begin{array}{c}\text { Экспериментальный прием } \\
\text { обработкиспила }\end{array}$} & \multicolumn{4}{|c|}{ Распространение болезни, вызванной возбудителем (\%) } \\
\hline Антисептирование & $\begin{array}{c}\text { Обработка } \\
\text { масляной краской }\end{array}$ & $\begin{array}{c}\text { Nectria } \\
\text { cinnabarina Wint. }\end{array}$ & $\begin{array}{l}\text { Ophiostoma ulmi } \\
\text { (Buisman) Melin \& Nannf. }\end{array}$ & $\begin{array}{l}\text { Родов Erwinia, } \\
\text { Pseudomonas }\end{array}$ & $\begin{array}{l}\text { Dothidella ulmi } \\
\text { (Duv.) Wint. }\end{array}$ \\
\hline \multicolumn{6}{|c|}{1 вариант, ул. им 64 Армии } \\
\hline \multicolumn{6}{|c|}{ обрезка второго года } \\
\hline$*$ & $*$ & 0,00 & 0,00 & 5,00 & 0,80 \\
\hline \multicolumn{6}{|c|}{ обрезка пятого года } \\
\hline- & $*$ & 9,18 & 2,45 & 19,15 & 12,46 \\
\hline \multicolumn{6}{|c|}{ контроль без обработки } \\
\hline- & - & 5,79 & 5,77 & 20,00 & 20,78 \\
\hline \multicolumn{6}{|c|}{ контроль без обрезки } \\
\hline- & - & 58,27 & 6,69 & 30,78 & 29,19 \\
\hline Уровень надеж & ности $(95,0 \%)$ & 69,89 & 19,09 & 108,00 & 88.90 \\
\hline \multicolumn{6}{|c|}{2 вариант, ул. Елецкая } \\
\hline \multicolumn{6}{|c|}{ обрезка второго года } \\
\hline$*$ & $*$ & 0,79 & 0,78 & 0,75 & 1,67 \\
\hline \multicolumn{6}{|c|}{ обрезка третьего года } \\
\hline$*$ & $*$ & 1,68 & 0,78 & 3,37 & 2,47 \\
\hline \multicolumn{6}{|c|}{ обрезка пятого года } \\
\hline- & $*$ & 12,45 & 2,49 & 5,69 & 8,90 \\
\hline \multicolumn{6}{|c|}{ контроль без обработки } \\
\hline- & - & 8,29 & 4,68 & 16,67 & 16,70 \\
\hline \multicolumn{6}{|c|}{ контроль без обрезки } \\
\hline- & - & - & 50,80 & 5,00 & 17,45 \\
\hline \multicolumn{2}{|c|}{ Уровень надежности $(95,0 \%)$} & 19,39 & 1,37 & 7,49 & 10,76 \\
\hline
\end{tabular}

Примечание. * - проведение защитного мероприятия. 
8. Кузнецова, Т. В. Экологическое обоснование оздоровления ильмовых пород в озеленении г. Волгограда : автореф. дис. ... канд. с.-х. наук / Татьяна Владимировна Кузнецова. - Волгоград, 2009. -24 c.

9. Кузьмичёв, Е. П. Инфекционные болезни городских насаждений и меры борьбы с ними / Е. П. Кузьмичёв, Э. С. Соколова, Е. Г. Куликова. М. : Изд-во МГУЛ, 2002. - 87 с.

10. Лукмазова, Е. А. Состояние популяций вязов на территории Летнего сада Санкт-Петербурга / Е. А. Лукмазова, Я. Ю. Кротова // VIII Чтения памяти О. А. Катаева. - СПб., 2014. - С. 46.

11. Мощеникова, Н. Б. Методическое пособие по изучению голландской болезни вязов / Н. Б. Мощеникова, Е. В. Вязникова. - СПб., 2016. - 43 с.

12. Озолин, Г. П. Опыт селекции ильмовых пород на устойчивость к голландской болезни / Г. П. Озолин // Вестник с.-Х. науки. - 1959. - № 12. C. 139-142.

13. Сенкевич, Н. Г. Устойчивая форма вяза мелколистного в культурах Северного Прикаспия / Н. Г. Сенкевич, Г. В. Линдеман // Лесоведение. 1984. - № 1.- С. 46-51.

14. Brasier, C. M. Ophiostoma himalulmi sp. nov., a new species of Dutch elm disease fungus endemic to the Himalayas / C. M. Brasier, M. D. Mehrotra // Myc. Res. - 1995. - Vol. 99, № 2. - P. 105-115.

15. Brasier, C. M. Ophiostoma novo-ulmi sp. nov., causative agent of current Dutch elm disease pandemics / C. M. Brasier // Mycopathologia. - 1991. Vol. 115. - P. 151-161.

16. Brasier, C. M. Designation of the EAN and NAN races of Ophiostoma novo-ulmi as subspecies / C. M. Brasier, S.A. Kirk // Myc. Res. - 2001. Vol. 105, № 5. - P. 547-554.

17. Brasier, C. M. Ophiostoma himal-ulmi sp. nov., a new species of Dutch elm disease fungus endemic to the Himalayas / C. M. Brasier, M. D. Mehrotra // Myc. Res. 1995. - Vol. 99. - № 2. - P. 105-115.

18. Brasier, C. M. Ophiostoma novo-ulmi sp. nov., causative agent of current Dutch elm disease pandemics / C. M. Brasier // Mycopathologia. - 1991. - Vol. 115. P. 151-161.

19. Interspecific hybridisation and interaction with cultivars affect the genetic variation of Ulmus minor and U. glabra in Flanders / K. Cox [et al.] // Tree Genetics and Genomes. - Vol. 10 (4). - 2014. - P. 813-826.

20. Gibbs, J. N. Dutch elm disease / J. N. Gibbs, D. A. Burdekin, C. M. Brasier // London : H. M. Stat. off. $-1977 .-12 \mathrm{p}$.

21. Phylogeny and taxonomy of the Ophiostoma picea complex and Dutch Elm Disease / T. C. Harrington [et al.] //Mycologia. - 2001. - Vol. 93 (1). - P. 111-136.

22. Heybroek, H. M. Notes on elm breeding and genetics / H. M. Heybroek // The Elms: Breeding,
Conservation, and Disease Management - Boston : Academic Publishers, 2000. - P. 249-258.

23. Heybroek, H. Iep of Olm - Karakterboom van de Lage Landen / H. Heybroek, L. Goudzwaard, H. Kaljee. - Zeist : KNNV uitgeverij, 2009. - 272 p.

24. Current status of the Dutch elm disease pathogen populations affecting Ulmus minor in Greece / G. T. Tziros, Z. G. Nakopoulou, C. Perlerou, S. Diamandis // Forest Pathology. - № 47 (2). - 2017. P. 1-10.

25. Webber, J. F. Experimental studies on factors influencing the transmission of Dutch elm Disease / J. F. Webber // Inwest. agr. sist y recurs. Forest. Vol. 1 (13). -2004. - P. 197-205.

\section{REFERENCES}

1. Verderevskij D.D. Immunitet rastenij $k$ parazitarnym boleznjam [Plant Immunity to Parasitic Diseases]. Moscow, Selhozgiz, 1959. 372 p.

2. Grudzinskaja I.A. Zametka ob Ulmus pumila L. [A note about Ulmus pumila L.]. Material gerbarija Botanicheskogo in-ta AN SSSR, 1961, vol. 21. 30 p.

3. Dudina, V.S. Gollandskaja bolezn ilmovyh porod: monografija [Dutch elm disease. Monograph]. M.oscow, Selhozgiz, 1938. 46 p.

4. Kalko G.V. Gollandskaja bolezn vjazov v SanktPeterburge [Dutch Elm Disease in St. Petersburg]. Mikologija i fitopatologija, 2008, vol. 42, no. 6, pp. 564-572.

5. Krjukova E.A., Kolmukidi S.V., Kuznecova T.V. Sosudistye patologii - ugroza vjazu v lesorazvedenii Povolzhja [Vascular pathologies - the threat to elm in afforestation in the Volga region]. Vestnik Rossijskoj akademii selskohozjajstvennyh nauk, 2013, no. 1, pp. 52-54.

6. Krjukova E.A., Kolmukidi S.V., Skuratov I.V. Sosudistye patologii v stepnom lesorazvedenii [Vascular pathologies in steppe afforestation]. Volgograd, VNIALMI, 2016. 134 p.

7. Krjukova E.A., Kuznecova T.V. Geterogennost ilmovyh i stepen patologicheskoj porazhaemosti v lesonasazhdenijah Nizhnego Povolzhyja [The heterogeneity of the elm and the degree of pathological affection in planted forests of the Lower Volga region]. Jekologija i melioracija agroladshaftov: materialy mezhdunar. nauchnopraktich. konf. molodyh uchenyh, Volgograd, VNIALMI, 2017, pp. 123-127.

8. Kuznecova T.V. Jekologicheskoe obosnovanie ozdorovlenija ilmovyh porod v ozelenenii g. Volgograda [Ecological substantiation of the recovery of the elm species in gardening in the city of Volgograd] : avtoref. dis. ... kand. s.-h. nauk. Volgograd, 2009. $24 \mathrm{p}$. 
9. Kuzmichjov E.P., Sokolova Je.S., Kulikova E.G. Infekcionnye bolezni gorodskih nasazhdenij i mery borby s nimi [Communicable diseases of urban plantations and measures to combat them]. Moscow, Izd-vo MGUL, 2002. $87 \mathrm{p}$.

10. Lukmazova E.A., Krotova Ja.Ju. Sostojanie populjacij vjazov na territorii Letnego sada SanktPeterburga [The status of elm populations in the territory of the Summer Garden of St. Petersburg]. VIII Chtenija pamjati O.A. Kataeva, Saint-Petersburg, 2014, p. 46.

11. Moshhenikova N.B., Vjaznikova E. V. Metodicheskoe posobie po izucheniju gollandskoj bolezni vjazov [Study Guide for the Study of Dutch Elm Disease]. Saint-Petersburg, 2016. 43 p.

12. Ozolin G.P. Opyt selekcii ilmovyh porod na ustojchivost $\mathrm{k}$ gollandskoj bolezni [Experience in breeding elm species for resistance to Dutch disease]. Vestniks.-h. nauki, 1959, no. 12, pp. 139-142.

13. Senkevich N.G., Lindeman G.V. Ustojchivaja forma vjaza melkolistnogo v kulturah Severnogo Prikaspija [The stable form of elm small-leaved in the cultures of the Northern Near-Caspian region]. Lesovedenie, 1984, no. 1, pp. 46-51.

14. Brasier C.M., Mehrotra M.D. Ophiostoma himalulmi sp. nov., a new species species of Dutch elm disease fungus endemic to the Himalayas. $M y c$. Res, 1995, vol. 99, no. 2, pp. 105-115.

15. Brasier C.M. Ophiostoma novo-ulmi sp. nov., causative agent of current Dutch elm disease pandemics. Mycopathologia, 1991, vol. 115, pp. 151-161.

16. Brasier C.M., Kirk S.A. Designation of theEAN and NAN races of Ophiostoma novo-ulmi as subspecies. Myc. Res, 2001, vol. 105, no. 5, pp. 547-554.
17. Brasier C.M., Mehrotra M.D. Ophiostoma himal-ulmi sp. nov., a new species of Dutch elm disease fungus endemic to the Himalayas. Myc. Res, 1995, vol. 99 , no. 2 , pp. 105-115.

18. Brasier C.M. Ophiostoma novo-ulmi sp. nov., causative agent of current Dutch elm disease pandemics. Mycopathologia, 1991, vol. 115, pp. 151-161.

19. Cox K. et al. Interspecific hybridisation and interaction with cultivars affect the genetic variation of Ulmus minor and U. glabra in Flanders. Tree Genetics and Genomes, 2014, vol. 10 (4), pp. 813-826.

20. Gibbs J.N., Burdekin J.N., Brasier C.M. Dutch elm disease. London : H. M. Stat. off, 1977. 12 p.

21. Harrington T.C. et al. Phylogeny and taxonomy of the Ophiostoma picea complex and Dutch Elm Disease. Mycologia, 2001, vol. 93 (1), pp. 111-136.

22. Heybroek H.M. Notes on elm breeding and genetics. The Elms: Breeding, Conservation, and Disease Management. Boston, Academic Publishers, 2000, pp. 249-258.

23. Heybroek H., Goudzwaard L., Kaljee H. Iep of Olm - Karakterboom van de Lage Landen. Zeist, KNNV uitgeverij, 2009. 272 p.

24. Tziros G.T., Nakopoulou Z.G., Perlerou C., Diamandis S.Current status of the Dutch elm disease pathogen populations affecting Ulmus minor in Greece. Forest Pathology, 2017, no. 47 (2), pp. 1-10.

25. Webber J.F. Experimental studies on factors influencing the transmission of Dutch elm Disease. Inwest. agr. sist y recurs. Forest, 2004, vol. 1 (13), pp. 197-205.

\section{Information about the Authors}

Elena A. Kryukova, Doctor of Sciences (Agricultural), Professor, Leading Researcher of the Laboratory of Bioecology of Woody Plants, Federal Scientific Centre of Agroecology, Complex Melioration and Protective Afforestation of the Russian Academy of Sciences, prosp. Universitetskiy, 97, 400062 Volgograd, Russian Federation, vnialmi@mail.ru.

Tatyana V. Kuznetsova, Candidate of Sciences (Agricultural), Junior Researcher, Laboratory of Bioecology of Woody Plants, Federal Scientific Centre of Agroecology, Complex Melioration and Protective Afforestation of the Russian Academy of Sciences, prosp. Universitetskiy, 97, 400062 Volgograd, Russian Federation, vnialmi@mail.ru.

Svetlana V. Kolmukidi, Candidate of Sciences (Agricultural), Leading Researcher, Laboratory of Biotechnology, Federal Scientific Centre of Agroecology, Complex Melioration and Protective Afforestation of the Russian Academy of Sciences, prosp. Universitetskiy, 97, 400062 Volgograd, Russian Federation; Associate Professor, Department of Biology, Volgograd State University, prosp. Universitetskiy, 100, 400062 Volgograd, Russian Federation, vnialmi@mail.ru. 


\section{БИОЛОГИЯ И БИОТЕХНОЛОГИЯ}

\section{Информация об авторах}

Елена Андреевна Крюкова, доктор сельскохозяйственных наук, профессор, ведущий научный сотрудник лаборатории биоэкологии древесных растений, Федеральный научный центр агроэкологии, комплексных мелиораций и защитного лесоразведения Российской академии наук, просп. Университетский, 97, 400062 г. Волгоград, Российская Федерация, vnialmi@mail.ru.

Татьяна Владимировна Кузнецова, кандидат сельскохозяйственных наук, младший научный сотрудник лаборатории биоэкологии древесных растений, Федеральный научный центр агроэкологии, комплексных мелиораций и защитного лесоразведения Российской академии наук, просп. Университетский, 97, 400062 г. Волгоград, Российская Федерация, vnialmi@mail.ru.

Светлана Валерьевна Колмукиди, кандидат сельскохозяйственных наук, ведущий научный сотрудник лаборатории биотехнологий, Федеральный научный центр агроэкологии, комплексных мелиораций и защитного лесоразведения Российской академии наук, просп. Университетский, 97, 400062 г. Волгоград, Российская Федерация; доцент кафедры биологии, Волгоградский государственный университет, просп. Университетский, 100, 400062 г. Волгоград, Российская Федерация, vnialmi@mail.ru 